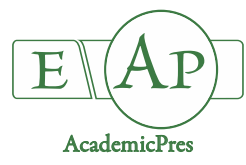

\title{
Effect of Nitrogen Fertiliser and Lime on the Floristic Composition, Soil Microbes and Dry Matter Yield of Danthonietum calycinae Grassland
}

\author{
Vladimir ZORNIĆ ${ }^{1}$, Vladeta STEVOVIĆ ${ }^{2}$, Zoran LUGIĆ ${ }^{1}$, \\ Snežana ANĐELKOVIĆ ${ }^{1}$, Goran JEVTIĆ ${ }^{1}$, Jasmina RADOVIĆ ${ }^{1 *}$, \\ Mirjana PETROVIĆ ${ }^{1}$ \\ IInstitutfor Forage Crops, 37251 Globoder,Kruševac, Serbia; vladimir.zornic@ikbks.com; zoran.lugic@ikbks.com; \\ snezana.andjelkovic@ikbks.com;goran.jevtic@ikbks.com; jasmina.radovic@ikbks.com (*correspondingauthor);mirjana.petrovic@ikbks.com \\ ${ }^{2}$ University of Kragujevac, Faculty of Agronomy, Cara Dušana 34, 32000 Čačak, Serbia; vladeta@kg.ac.rs
}

\begin{abstract}
Natural grasslands are significant resources for forage production, which is not exploited enough, mostly because of low production, as a result of bad grasslands management. The research has been carried out on the association Danthonietum calycinae to evaluate the effects of different nitrogen application rates $\left(\mathrm{N}_{20}, \mathrm{~N}_{80}\right.$ and $\left.\mathrm{N}_{140}\right)$ and lime (1 tha $\left.{ }^{-1}\right)$ on the floristic composition, soil microbes and dry matter yield. Botanic composition was strongly influenced by the treatments, especially by $\mathrm{N}$ applications. Nitrogen fertilisation led to significant increase of grass species in the association (from $57 \%$ to $82 \%$ ), while higher rate of nitrogen caused a significant decrease of plants from other families (especially legumes). Application of low and medium rate of nitrogen positively effect on microbial abundant in soil, but the highest dose $(140 \mathrm{~kg} \mathrm{~N})$ reduced all microbial count, except fungi. Mineral nitrogen fertilisation had a favourable effect on dry matter yield in all treatments. The highest increase in dry matter yield relative to the control was in $\mathrm{N}_{140}$ treatments $\left(6.66 \mathrm{t} \mathrm{ha}^{-1}\right)$. Results indicated that optimal applications of nutrients for this association is application of PK and lime and $80 \mathrm{~kg}$ of nitrogen which enable high yield $(6.38 \mathrm{t}$ $\left.\mathrm{ha}^{-1}\right)$ in comparison with control $\left(3.16 \mathrm{tha}^{-1}\right)$ and preserving soil fertility and the environment at the same time.
\end{abstract}

Keywords: fertilisation; hay yield; meadow; microorganisms; plant diversity

\section{Introduction}

Natural grasslands represent one of the major resources in agriculture which are distributed in a wide range from lowland to hilly mountain regions. Current management practice, mainly related to extensive use and inadequate treatment, cause further decline of floristic diversity, as well as additional degradation of grasslands, either related to reduced yields or expansion of undesirable species.

Yield increases on grasslands are most effectively achieved under mineral fertilisation (Honsova et al., 2007). Among nutrients, nitrogen is the most frequently applied nutrient to grass dominated communities because of the high $\mathrm{N}$ requirement of grasses for growth and faster and the highest effect on yield (Le Bauer and Treseder, 2008). Favourable effects of nitrogen fertilisation on grassland yield in different grassland association were reported by Lazarević et al. (2009) and Hrevusova et al. (2015). However, the nitrogen application at high rates increase dry matter yield, but also can induce a number of negative economic and environmental effects (Acosta-Martinez and Tabatabai, 2000).

Application of nitrogen cause great changes in plant cover, resulting in an increased presence of Poaceae species (Hejcman et al., 2007) and usually decreasing of plants from other families (Čop et al., 2009). Mineral nitrogen has a particularly negative effect on legumes, potentially resulting in their disappearance (Velich, 1986; Honsova et al., 2007) Continuous mineral nitrogen inputs into the grassland ecosystem cause a rapid decline in overall biodiversity (Stošić et al., 2004).

Mineral nitrogen fertilisation usually changes the numbers of microorganisms as the most active biological group in the soil. Therefore, soil microbial abundance can serve as an indicator of environmental justification for the rate and type of mineral fertilisers applied (Stark et al., 2007). Another negative effect of high nitrogen application 
1056

rates is the growth of fungi which produce toxic substances, particularly from the genus Penicilium (Pešakovic et al., 2009).

Natural grasslands in hilly mountain areas mostly spread on poor soil, with low $\mathrm{pH}$ value. Floristic composition and soil microbial abundance are largely affected by soil acidity. At low soil $\mathrm{pH}$, the availability of carbon and other nutrients is reduced (Kemmitt et al., 2005). In acid soils, the presence of legumes is decreased, while grasses which are tolerant to low $\mathrm{pH}$ are dominant. At low $\mathrm{pH}$, soil microbial activity is reduced; at extremely low $\mathrm{pH}$, the most of microbiological processes in the soil are blocked (Rouck et al., 2009). Moreover, low pH has a strong inhibitory effect on the biological nitrogen fixation. This is primarily due to the decreased number or absence of Azotobacter, important free-living nitrogen fixing bacterium (Milošević et al., 2007) and also other groups of free-living nitrogen fixing bacteria, such as Azospirillum, Bacillus and Klebsiella spp. As this nitrogen fixing bacteria can fix up to $150 \mathrm{~kg} \mathrm{ha}^{-1}$ nitrogen (Elgersma and Hassink, 1997), the reduction in their number lead to yield declines. Because of all that, increasing of soil $\mathrm{pH}$ value, usually by lime applications, is one of the important measures in grassland utilization.

The potential of huge grassland areas of the hilly mountainous region of Serbia is not sufficiently exploited. Effect on agricultural measures on grasslands depends first of all on floristic components and potential productivity of any associations. One of the ten economically most important communities in hilly mountains vegetation in Serbia is Danthonietum calycinae.

In central parts of the Balkans, the association Danthonietum calycinae occurs on gentle slopes with different exposures, mostly at altitudes between 600 and $1,100 \mathrm{~m}$. The plant species Danthonia calycina has a very wide range, its natural habitat spanning Europe, North Africa and East Asia (Valdés et al., 2009). Association Danthonietum calycinae belongs to class Festuco-Brometea, order - Brometalia erecti, alliance - ChrysopogoniDanthonion calycinae. It's a very stable association, dominated by perennial grass species with numerous plants species (Mrfat Vukelić et al., 1991). From 79 plant species, which could be part of association, 22 species is common as: Danthonia calycina, Filipendula hexapetala, Achillea millefolium, Agrostis vulgaris, Trifolium montanum, Galium verum (Kojić et al., 2004). The most plant species (79.7\%) belongs to hemicryptophyte, and others are terophyta (10.1\%), geophyta (6.4\%) and hemiphyta (3.8\%). Dry matter yields of this type of grassland under unfertilised conditions vary from 1.5 to $2.85 \mathrm{t} \mathrm{ha}^{-1}$ (Vučković, 2004).

Application of adequate management practice could both prevent further degradation of grasslands and related biodiversity loss and improve grassland quality and productivity. A detailed knowledge of community may provide the scientific basis for designing management plants that would be proper for maintaining the biodiversity of particular association. Determination of optimum nitrogen rates, with or without liming, to achieve good yields while preserving the biodiversity of natural grasslands and soil microbiological activity is an important task of agricultural practice. The objective of this study was to investigated effect of different rates of mineral nitrogen fertiliser and liming on the floristic composition, soil microbes (total microbial, fungal, actinomycetes, Klebsiella planticola and Azotobacter), and dry matter yield of Danthonietum calycinae association.

\section{Materials and Methods}

\section{Locations and weather conditions}

The research was conducted on the association classified as Danthonietum calycinae (Cincović and Kojić, 1955). The grassland was located in Central Serbia, at Mitrovo Polje $\left(43^{\circ} 30^{\prime} \mathrm{N}, 20^{\circ} 52^{\prime} \mathrm{E} ; 684 \mathrm{~m}\right.$ altitude). Weather conditions during investigation, according to Republic hydro meteorological service of Serbia, was characterised by moderate air temperature and precipitation values (Table 1).

The parameters of soil fertility showed that grassland growth on shallow soil, which was extremely acid $\left(\mathrm{pH}_{\mathrm{KCl}}\right.$ 4.09), poor in phosphorus (2.65 $\mathrm{mg} \mathrm{kg}^{-1}$ ) and potassium $\left(7.96 \mathrm{mg} \mathrm{kg}^{-1}\right.$ ), with high level of organic matter $(8.96 \%)$.

\section{Experimental design}

The experiment was laid out in a split plot design. Plot size was $10 \mathrm{~m}^{2}$, in 4 replications of each treatment. Each plot was separated with protection borders of $0.5 \mathrm{~m}$ within blocks and $1 \mathrm{~m}$ between blocks.

The main investigation factors were application of different nitrogen rates $\left(\mathrm{N}_{0}, \mathrm{~N}_{20}, \mathrm{~N}_{80}\right.$ and $\mathrm{N}_{140}$-subscripts after $\mathrm{N}$ denote the rate of pure nitrogen per hectare) and lime (without lime $\mathrm{L}_{0}$ and with $1 \mathrm{t} \mathrm{ha}^{-1}$ lime $\mathrm{L}_{1}$ ), providing 8 experimental treatments as follow: $\mathrm{N}_{0} \mathrm{~L}_{0}, \mathrm{~N}_{20} \mathrm{~L}_{0}, \mathrm{~N}_{80} \mathrm{~L}_{0}$, $\mathrm{N}_{140} \mathrm{~L}_{0}, \mathrm{~N}_{0} \mathrm{~L}_{1}, \mathrm{~N}_{20} \mathrm{~L}_{1}, \mathrm{~N}_{80} \mathrm{~L}_{1}, \mathrm{~N}_{140} \mathrm{~L}_{1}$.

Liming was performed as surface treatment, at the beginning of the experiment in autumn 2012, with hydrated lime $\left(\mathrm{Ca}(\mathrm{OH})_{2}\right)$. All treatments were fertilised in autumn 2012 and 2013 with phosphorus and potassium at $60 \mathrm{~kg} \mathrm{ha}^{-1}$. Phosphorus was incorporated as single superphosphate $\left(\mathrm{P}_{2} \mathrm{O}_{5}, 18.5 \%\right.$ phosphorus), and potassium as potassium chloride ( $\mathrm{KCl}, 60 \%$ potassium). Nitrogen was applied in spring 2013 and 2014 i.e. in mid-March, in the form of ammonium nitrate $\left(\mathrm{NH}_{4} \mathrm{NO}_{3} 33 \%\right)$.

\section{Floristic composition}

Species composition was determinate on herbage samples, which were taken from $0.7 \mathrm{~m} \times 0.7 \mathrm{~m}$ area, which was randomly selected within every plot. Cutting was performed at beginning of heading of main grassland component on $4 \mathrm{~cm}$ height by scissors, before harvesting all plots.

Table 1. Mean monthly precipitation $(\mathrm{mm})$ and mean temperatures during experiment

\begin{tabular}{|c|c|c|c|c|c|c|c|c|c|c|c|c|}
\hline Month & I & II & III & IV & V & VI & VII & VIII & IX & $\mathrm{X}$ & XI & XII \\
\hline $\mathrm{T}^{\circ} \mathrm{C}$ & 3.1 & 4.7 & 5.5 & 7.6 & 10.9 & 14.9 & 17.0 & 17.0 & 12.7 & 8.8 & 6.2 & 0.7 \\
\hline Precip. & 13.7 & 16.4 & 15.2 & 257.3 & 256.9 & 148.1 & 136.2 & 137.5 & 170.3 & 78.7 & 51.4 & 118.2 \\
\hline
\end{tabular}


Plant species were determined and classified on 5 functional plant group according to their traits (tall grasses, short grasses, tall herbs, short herbs and legumes), for easier observing influence of nitrogen and lime on vertical plant distribution in association (Čamska and Skalova, 2012). According to results about plant height, which was measured in this association, Festuca rubra is classified as tall grass. Weight of every functional group was measured and the percentages of every functional plant groups were calculated on a fresh biomass.

\section{Soilmicrobes}

The soil samples collected from the rhizosphere at a depth of 0 to $20 \mathrm{~cm}$ were used for microbiological analyses. Sampling was performed by a soil sampler, at the beginning of June 2014, just after cutting of all plots. Soil samples were taken from each treatment, in three replications.

Microbial numbers were determined by the agar plate count method on appropriate selective culture media (Jarak et al., 2006). The microbial estimation involved testing for the presence and number of the following systematic and physiological groups of microorganisms:

1. Total microbes were determined on a soil agar, after inoculation of $0.5 \mathrm{ml}$ of a $10^{-6}$ dilution of soil suspension;

2. Actinomycetes were determined on Krasilnikov's synthetic agar, after inoculation of $0.5 \mathrm{ml}$ of a $10^{-4}$ dilution of soil suspension;

3. Fungi were determined on Chapek's agar, after inoculation of $0.5 \mathrm{ml}$ of a $10^{-4}$ dilution of soil suspension;

4. Klepsiella planticola in the rhizosphere were determined by the method of Emstev et al. (2000) at a $10^{-3}$ dilution of soil suspension;

5. Azotobacter was determined by the "fertile drops" method on Fedorov's medium, after inoculation of $0.2 \mathrm{ml}$ of a $10^{-1}$ dilution of soil suspension.

Concentrations of colony-forming units were expressed using logarithmic notation and calculated per gram of absolutely dry soil.

\section{Dry matter yield}

Forage yield was determined by harvesting the first cut at the beginning of June. Samples of $1 \mathrm{~kg}$ herbage were collected from each treatment, dried at $60^{\circ} \mathrm{C}$ to a constant weight and then recalculated as dry matter yield $\left(\mathrm{tha}^{-1}\right)$.

\section{Statistical analyses}

Differences between plants functional groups and differences in average dry matter yield were tested by LSD post-hoc test following main effects ANOVA. Differences in the soil microbial count were analysed with a two-way factorial ANOVA and Fisher LSD test considering fertilizer and lime as factors. Pearson's partial correlation coefficient was calculated among percentage proportions of the functional groups and soil microbes count. Principal component analysis (PCA) was further applied to help to explain relationships between fertilizer rate, liming regime, proportion of functional groups and soil microbe's count.

The statistical analyses were performed using the program STATISTICA 8 (StatSoft, Inc., Tulsa, OK, USA).

\section{Results}

\section{Floristic composition}

According to results of floristic analysis, investigated association Danthonietum calycinae was consist of numerous plant species. All species were determined and according to their main traits, were classified in five functional groups as follow:

Tall grasses: Chrysopogon gryllus, Festuca rubra, Holcus lanatus

Short grasses: Agrostis vulgaris, Anthoxanthum odoratum, Briza media, Cynosurus cristatus, Danthonia calycina

Tall herbs: Betonica officinalis, Filipendula hexapetala, Hieracium baubinii, Rumex acetosella,

Short herbs: Achillea millefolium aggregatum, Allium sp., Carex sp., Centaurea jacea, Cerastium holosteoides, Dianthus deltoides, Euphrasia stricta, Galium verum, Genista tinctoria, Luzula sp., Myosotis arvensis, Plantago lanceolata, Ranunculus acer, Stellaria graminea, Veronica sp.

Legumes: Lotus corniculatus, Ononis spinosa, Trifolium campestre, Trifolium montanum, Trifolium pratense, Trifolium repens, Trifolium retusum, Vicia sp., Lathyrus pratensis

The floristic composition in the unfertilised control showed that grasses were dominant species. Short grasses, represented with 5 species, were dominant species with over $35 \%$ in the total biomass. Tall grasses had 3 species, with about $15 \%$ of total mass; numerous short herbs ( 15 species) participate in the yield with over of $25 \%$. Tall herbs (4 species) and legumes ( 6 species) achieved in yield about $10 \%$ each.

Species composition was strongly influenced by the treatments, especially by $\mathrm{N}$ applications. A statistically significant increase of tall grasses relative to the control was observed in all treatments involving nitrogen fertilization (Table 2). The proportion of this functional group ranged from $18.55 \%$ (control) to $30.18 \%$ ( $\mathrm{N}_{140}$ treatments). Short grasses, as dominant plant functional group, positively reflected on $\mathrm{N}$ application, with increasing $\mathrm{N}$ rate, the amount of short grasses is also increased.

Nitrogen application had quite opposite effect on other plant group on investigated association. The percentage of tall herbs in harvested biomass was lower in nitrogen fertilisation treatments than in the control (6.92\%) and decreased with increasing of application rate. A similar influence was recorded on the short herbs. With an increase of nitrogen rate, there was a continuous decline in the proportion of short herbs in harvested biomass. The highest percent contribution of the short herbs to harvested biomass was in control treatments (25.27), and the lowest in $\mathrm{N}_{140}$ treatments (15.43). A rapid decline for both groups was recorded at higher nitrogen rate, while low nitrogen application $\left(\mathrm{N}_{20}\right)$ did not cause significant differences.

The application of mineral nitrogen discouraged the legume development, as evidenced by the significantly lower percentage of this functional group in all nitrogen treatments. Treatments with $\mathrm{N}_{80}$ and $\mathrm{N}_{140}$ gave a markedly low proportion of legumes, amounting to 0.03 and 0.13 , 
1058

respectively. A significant decline in the number of species was found only in $\mathrm{N}_{140}$ treatments. Liming had a depressive effect on tall grasses, while other plant groups reacted positively on lime application, but observed differences were not significant.

The results in the PCA plot (Fig. 1), showing the proportions of particular functional groups, indicate that $89.8 \%$ of the total variance was explained by the two axes presented i.e.by the first two components. The first axis accounted for $69.7 \%$ of the total variance. The first component was strongly positively correlated with the proportions of tall and short grasses, and negatively correlated with the percentage of legumes in harvested biomass. The second main component explained $20.1 \%$ of the total variance, and was positively correlated with the proportion of short herbs proportions, but negatively correlated with tall herbs. The $\mathrm{N}_{140}$ treatments with and without lime and $\mathrm{N}_{80}+$ lime treatment were favourable for grass development. The proportion of short herbs increased in $\mathrm{N}_{0}, \mathrm{~N}_{20}$ and $\mathrm{N}_{80}$ treatments combined with liming, whereas tall herbs were favoured in $\mathrm{N}_{0}$ treatments. Nitrogen-free treatments supported legume development.

\section{Soilmicrobes}

Mineral nitrogen fertilisation led to a significant increase in total microbial counts in all treatments (Table 3). Total microbial counts ranged from 7.52 to 8.38 , and were the

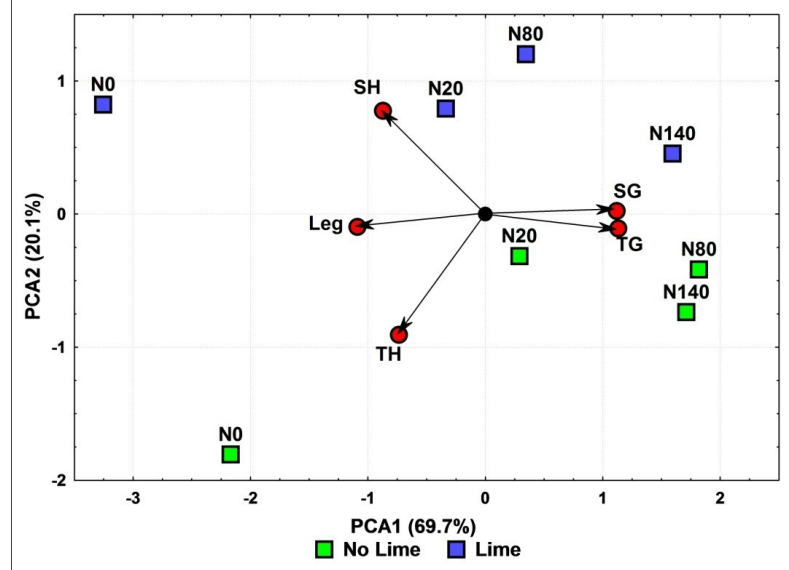

Fig. 1. Component loadings of the first two principal components of PCA of functional plants groups. TG = Tall grasses, $\mathrm{SG}-$ Short grasses, $\mathrm{TH}=$ Tall herbs, $\mathrm{SH}=$ Short herbs, Leg $=$ Legumes highest at $\mathrm{N}_{20}$. Liming had a significantly positive effect on total microbial counts, resulting in their significant increase in control, $\mathrm{N}_{20}$ and $\mathrm{N}_{80}$ treatments, whereas no effect was produced under $\mathrm{N}_{140}$ (Fig. 2a). The fertiliser $\mathrm{x}$ lime interaction was statistically significant.

The numbers of actinomycetes in the soil were significantly stimulated by mineral nitrogen fertilisation and liming (Table 3). The highest actinomycetes counts were obtained in $\mathrm{N}_{20}$ treatment (3.89). Liming had a significant stimulatory effect on the counts of actinomycetes in all treatments, except control (Fig. 2b). The fertiliser x lime interaction was statistically significant.

Soil fungi number significantly increased at all mineral nitrogen application rates (Table 3), and ranged from 4.51(control) to $5.69\left(\mathrm{~N}_{140}\right)$. A decline in fungal numbers was observed in treatments involving liming (Fig. 2c). The numbers of Klebsiella planticola were significantly affected by nitrogen fertilisation, liming and the fertiliser $\mathrm{x}$ lime interaction (Table 3). Klebsiella planticola were encouraged by treatments with $20 \mathrm{~kg} \mathrm{~N} \mathrm{ha-1}$, but discouraged by increased rates of this nutrient. Liming had a stimulatory effect on Klebsiella planticola in all nitrogen treatments.

As shown in the PCA plot of microbial counts, the first main component accounted for $53.8 \%$ of the total variance. The first component was strongly negatively correlated with total microbes, actinomycetes and Klebsiella planticola number. The second component explained $38.1 \%$ of the total variance, and was negatively correlated with the count of fungi in the soil. Treatments with $\mathrm{N}_{80}$ and $\mathrm{N}_{140}$ favoured fungal growth. The rate of nitrogen most favourable for the growth of actinomycetes was $80 \mathrm{~kg} \mathrm{ha}^{-1}$ combined with lime, while the low nitrogen rate $(20 \mathrm{~kg} \mathrm{ha})$ was suitable for the growth of Klebsiella planticola (Fig. 3).

A positive and significant correlation was determined between soil fungal number and the proportions of tall and short grasses, while fungi was in negative correlation with other plant functional groups (Table 4). The counts of Klebsiella planticola were positively correlated with the proportion of short herbs. Negative correlations were noticed between grasses and Klebsiella planticola, and effect of tall herbs and legumes on investigated soil microbial group were also negative, but differences were no significant.

\section{Dry matter yield}

Application of mineral nitrogen had a strongly effect on dry matter yield in all treatments. Even small amounts of nitrogen $\left(20 \mathrm{~kg} \mathrm{ha}^{-1}\right)$ significantly increased dry matter yield, from 3.41 to $4.81 \mathrm{t} \mathrm{ha}^{-1}$ (Table 5).

Table 2. Effect of nitrogen and lime application on functional plant groups presence (\%)

\begin{tabular}{|c|c|c|c|c|c|c|c|}
\hline Trea & Plant group & $\begin{array}{c}\text { Tall grasses } \\
(\%)\end{array}$ & $\begin{array}{c}\text { Short grasses } \\
(\%)\end{array}$ & $\begin{array}{c}\text { Tall herbs } \\
(\%)\end{array}$ & $\begin{array}{c}\text { Short herbs } \\
(\%)\end{array}$ & $\begin{array}{c}\text { Legumes } \\
(\%)\end{array}$ & Number of species \\
\hline \multirow{4}{*}{ 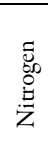 } & $\mathrm{N}_{0}$ & $18.55 \mathrm{~b}$ & $38.45 c$ & $6.92 \mathrm{a}$ & $25.27 \mathrm{a}$ & $10.81 \mathrm{a}$ & $30.50 \mathrm{a}$ \\
\hline & $\mathrm{N}_{20}$ & $26.53 a$ & $42.97 \mathrm{bc}$ & $6.13 a$ & $24.11 \mathrm{a}$ & $0.26 b$ & $30.00 \mathrm{a}$ \\
\hline & $\mathrm{N}_{80}$ & $27.09 \mathrm{a}$ & $50.17 \mathrm{ab}$ & $2.51 \mathrm{~b}$ & $20.20 \mathrm{ab}$ & $0.03 b$ & $26.50 \mathrm{ab}$ \\
\hline & $\mathrm{N}_{140}$ & $30.18 \mathrm{a}$ & $51.97 \mathrm{a}$ & $2.29 \mathrm{~b}$ & $15.43 b$ & $0.13 b$ & $18.50 \mathrm{~b}$ \\
\hline \multirow{2}{*}{$\stackrel{\mathscr{\Xi}}{\Xi}$} & Lo & $26.81 \mathrm{~A}$ & $44.42 \mathrm{~A}$ & $5.45 \mathrm{~A}$ & $20.82 \mathrm{~A}$ & $2.50 \mathrm{~A}$ & $25.50 \mathrm{~A}$ \\
\hline & $\mathrm{L}_{1}$ & $22.20 \mathrm{~B}$ & $46.36 \mathrm{~A}$ & $4.25 \mathrm{~A}$ & $23.61 \mathrm{~A}$ & $3.58 \mathrm{~A}$ & $27.25 \mathrm{~A}$ \\
\hline
\end{tabular}

Note: Columns followed by same letter $(s)$ do not differ significantly $(\mathrm{p}<0.05)$ 
1059

Increasing nitrogen rates led to a significant increase in dry matter yield and the highest dry matter yield relative to the control was observed in $\mathrm{N}_{140}$ treatments $\left(6.66 \mathrm{t} \mathrm{ha}^{-1}\right)$. Application of lime had lower, but not less important, positive influence on grassland production. The significant effect of lime was observed at all nitrogen application rates, except in $\mathrm{N}_{20}$ treatments.

Table 3. Effect of treatments on investigated microbial groups abundance (means \pm standard deviations)

\begin{tabular}{|c|c|c|c|c|c|}
\hline & & Total microbes $\left(10^{-6}\right)$ & Actinomycetes $\left(10^{-4}\right)$ & Fungi $\left(10^{-4}\right)$ & K. planticola $\left(10^{-3}\right)$ \\
\hline \multirow{4}{*}{$\begin{array}{l}\text { 范 } \\
\text { : } \\
\text { Z }\end{array}$} & $\mathrm{N}_{0}$ & $7.52 \pm 0.30 \mathrm{c}$ & $3.03 \pm 0.15 \mathrm{c}$ & $4.51 \pm 0.23 \mathrm{~d}$ & $4.18 \pm 0.18 \mathrm{~b}$ \\
\hline & $\mathrm{N}_{20}$ & $8.38 \pm 0.28 \mathrm{a}$ & $3.88 \pm 0.44 \mathrm{a}$ & $4.89 \pm 0.35 \mathrm{c}$ & $4.34 \pm 0.19 \mathrm{a}$ \\
\hline & $\mathrm{N}_{80}$ & $8.02 \pm 0.25 b$ & $3.84 \pm 0.25 \mathrm{a}$ & $5.26 \pm 0.21 b$ & $3.95 \pm 0.15 \mathrm{c}$ \\
\hline & $\mathrm{N}_{140}$ & $7.87 \pm 0.23 \mathrm{~b}$ & $3.37 \pm 0.19 \mathrm{~b}$ & $5.69 \pm 0.07 \mathrm{a}$ & $3.81 \pm 0.34 \mathrm{~d}$ \\
\hline \multirow{2}{*}{ 节 } & Lo & $7.81 \pm 0.38 \mathrm{~B}$ & $3.36 \pm 0.29 \mathrm{~B}$ & $5.24 \pm 0.45 \mathrm{~A}$ & $3.89 \pm 0.27 \mathrm{~B}$ \\
\hline & $\mathrm{L}_{1}$ & $8.09 \pm 0.39 \mathrm{~A}$ & $3.70 \pm 0.52 \mathrm{~A}$ & $4.94 \pm 0.52 \mathrm{~B}$ & $4.25 \pm 0.20 \mathrm{~A}$ \\
\hline \multirow{3}{*}{$\begin{array}{l}\text { य } \\
0 \\
z\end{array}$} & Nitrogen & ** & ** & ** & ** \\
\hline & Lime & ** & ** & ** & ** \\
\hline & Nitrogen $\mathrm{x}$ lime & * & * & NS & ** \\
\hline
\end{tabular}

Note: Values followed by different letters are significantly different $(\mathrm{p}<0.05)$ according to the LSD test; $F$ test significant at $\mathrm{P} \leq 0.05 ; \mathrm{F}$ test significant at $\mathrm{P} \leq 0.01, \mathrm{~N} s$ - no significant

Table 4. The partial correlation coefficients between the soil microbes and the plant functional groups

\begin{tabular}{ccccc}
\hline & $\begin{array}{c}\text { Total microbes } \\
\left(10^{-6}\right)\end{array}$ & $\begin{array}{c}\text { Actinomycetes } \\
\left(10^{-4}\right)\end{array}$ & $\begin{array}{c}\text { Fungi } \\
\left(10^{-4}\right)\end{array}$ & $\begin{array}{c}\text { Klebsiella } \\
\text { planticola }\left(10^{-3}\right)\end{array}$ \\
\hline Tall grasses (\%) & 0.40 & 0.36 & $0.86^{* *}$ & -0.53 \\
Short grasses (\%) & 0.09 & 0.33 & $0.92^{* *}$ & -0.55 \\
Tall herbs (\%) & -0.57 & -0.54 & -0.49 & 0.02 \\
Short herbs (\%) & 0.32 & 0.21 & $-0.84^{* *}$ & $0.82^{*}$ \\
Legumes (\%) & -0.55 & -0.67 & $-0.75^{*}$ & 0.30 \\
\hline Note: Correlations are significant $\left({ }^{*} \mathrm{p}<0.05{ }^{* *} \mathrm{p}<0.01\right)$ & & &
\end{tabular}

Table 5. Production of grassland influenced by $\mathrm{N}$ fertilising and liming $\left(\mathrm{t} \mathrm{ha}{ }^{-1} \mathrm{DM}\right)$

\begin{tabular}{cccccc}
\hline & $\mathrm{N}_{0}$ & $\mathrm{~N}_{20}$ & $\mathrm{~N}_{80}$ & $\mathrm{~N}_{140}$ & Average \\
\hline $\mathrm{L}_{0}$ & $3.16 \mathrm{f}$ & $4.76 \mathrm{~d}$ & $5.66 \mathrm{c}$ & $6.34 \mathrm{~b}$ & $4.98 \mathrm{~B}$ \\
$\mathrm{~L}_{1}$ & $3.66 \mathrm{e}$ & $4.86 \mathrm{~d}$ & $6.38 \mathrm{~b}$ & $6.98 \mathrm{a}$ & $5.47 \mathrm{~A}$ \\
Average & $3.41 \mathrm{D}$ & $4.81 \mathrm{C}$ & $6.02 \mathrm{~B}$ & $6.66 \mathrm{~A}$ & \\
\hline Note: Columns followed by same letter(s) do not differ significantly $(\mathrm{p}<0.05)$ & & &
\end{tabular}
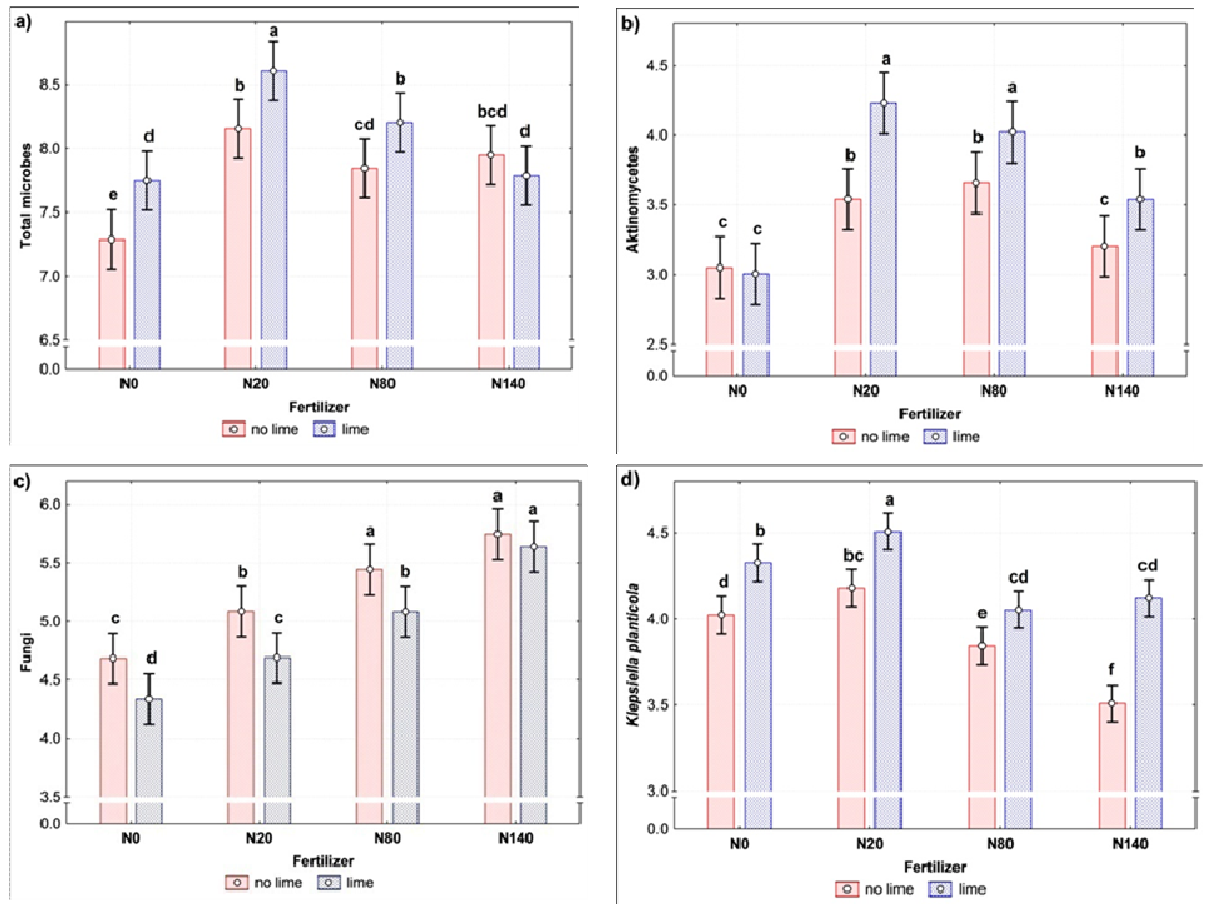

Fig. 2. Abundance of total microbes (a), actinomycetes (b) fungi (c) and Klebsiella planticolae (d) affected by nitrogen and lime application. Error bars show $95 \%$ confidence interval. (Same letter $(s)$ do not differ significantly $(\mathrm{p}<0.05)$ ) 
1060

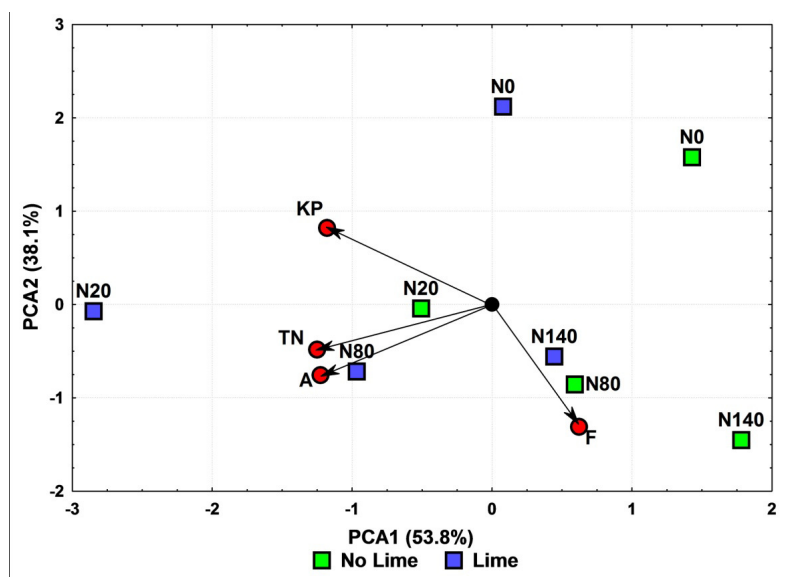

Fig. 3. Component loadings of the first two principal components of PCA of soil microbes. $\mathrm{TN}=$ Total number, $\mathrm{A}$ $=$ Actinomycetes, $\mathrm{F}=$ Fungi, $\mathrm{KP}=$ Klepsiella planticola

\section{Discussion}

The management of permanent grasslands, primarily fertilisation, has a great influence on plant biodiversity, soil microbial activity and first of all on dry matter yield. An effect of a fertiliser on grassland productivity and botanic composition depends on productive potential of association, soil quality, weather condition, and also on the rate and the period of application.

An application of mineral nitrogen strongly enhances changes in species composition and increase biomass production on grasslands, but also could have same negative effects such as a decline in biodiversity, as a consequence of increased competition for light and nutrients. Even the lowest nitrogen application rate $\left(\mathrm{N}_{20}\right)$ led to a significant increase in the proportion of forage grasses which had a positive effect on both dry matter yield and a quality of forages. Hrevusova et al. (2015) also reported that a small amount of nitrogen could increase the presence of tall grasses in associations. Grasses are very competitive species, due to their excellent utilization of nitrogen and tolerance of low soil $\mathrm{pH}$, they grow fast and suppress plants from other families. The increase in the proportion of tall grasses was accompanied by a strong decrease in a proportion of legumes in the grassland. Except legumes, plant species from other families are not desirable on grasslands, because of a decrease forage quality and, in some cases, could have a negative effect on animal's health. An evident decrease in the proportion of plants species from other families on higher application rates, reported by Čop et al. (2009).

The highest nitrogen application rate $\left(\mathrm{N}_{140}\right)$, had a negative effect on the number of plant species (decreased from 30 at 18), while biodiversity was preserved on a lower rate of applied nitrogen. Stošić et al. (2004) found that the number of species on heavily fertilised grasslands decreased from 20 to fewer. In the last several decades, this type of biodiversity disturbance has been observed in intensively fertilised grasslands in Western and Central Europe, whereas a high level of diversity has been found only in marginal grasslands where no heavy fertilisation is used (Spiegelberger et al., 2006; Smith et al., 2008). The ultimate effect of the long-term use of high nitrogen rates is the disappearance of some species from grasslands, primarily those of legumes (Honsova et al., 2007). On the contrary of that liming could reduce the proportion of tall grasses, while having no significant effect on other groups of plants. Longterm application of phosphorus, potassium and lime had an effect on floristic composition, specially increasing legumes and indirectly increasing yield and directly improving the forage quality. Similar results were reported by Hejcman et al. (2010).

Applications of nutrients, especially nitrogen, could have disbalansed microbial activity in soil, as important indicator of soil fertility. The highest total microbial counts and abundance of actinomyces and Klebsiella planticola were determined in treatments with lower nitrogen application rates $\left(\mathrm{N}_{20}\right.$ and $\left.\mathrm{N}_{80}\right)$, as the mineralisation of organic matter is most pronounced under such conditions. Higher rate of nitrogen have negative effect on microbial activity in soil due to changes in soil physical and chemical properties (Stark et al., 2007). Another reason was a decline in the biodiversity of plant species. Plants establish a positive feedback relationship with rhizosphere microorganisms through root-specific secondary metabolites; therefore, any loss of plant species consequently causes disappearance of some species of microorganisms which have entered into the mutual relationship. The highest rate of nitrogen $\left(\mathrm{N}_{140}\right)$ decreased number of all soil microbes, except for fungi. An increase in fungal counts can be considered as a useful process, given the important role of fungi in the cycle of nutrients, proteolysis, phosphorus dissolution and mobilisation, and other processes in grassland ecosystems. The incorporation of nitrogen has a favourable effect on soil fungi (Stanojković et al., 2014), while liming led to a decrease in fungal counts (Rouck et al., 2009). Mandić et al. (2012) also found that the numbers of actinomycetes in a vertisol, induced by increasing nitrogen application rates $(90,120,150)$. Jagnow (1983) found that the activity of Klebsiella and Enterobacter spp. was significantly higher at $\mathrm{N}_{0}$ and $\mathrm{N}_{80}$ than at $\mathrm{N}_{120}$. In this research, no presence of Azotobacter was determined, given that the initial soil was not suitable for the development of this bacterium, due to its extremely acid chemical reaction and low phosphorus content.

A significant positive correlation between the proportions of grasses and fungi was a result of a high degree of mycorrhizal colonisation of grass roots (Vandenkoornhuyse et al., 2003; Kennedy et al., 2005). The negative correlation between fungi and legumes was attributed to the production of fungal cell wall degrading enzymes by some nitrogen fixing bacteria, symbiotic or freeliving (Waler et al., 2002).

The application of mineral nitrogen had a favourable effect on dry matter yield in all treatments. The highest increase in dry matter yield relative to the control was in $\mathrm{N}_{140}$ treatments $\left(6.66 \mathrm{t} \mathrm{ha}^{-1}\right.$ ), but differences between $\mathrm{N}_{140}$ and $\mathrm{N}_{80}$ is not so high. This significant increase was associated with high PK fertiliser application rates $(60 \mathrm{~kg} \mathrm{ha}$ $\left.{ }^{1}\right)$ on the one hand, and with the increased amount of precipitation during the study year, particularly in April and May, on the other. Lazarević et al. (2009) reported an increase in dry matter yield with increasing rates of nitrogen 60,80 and $100 \mathrm{~kg} \mathrm{ha}^{-1}$, with no significance found for the increase from 80 to $100 \mathrm{~kg} \mathrm{ha}^{-1}$. 


\section{Conclusions}

Production of grasslands can be increased in a very short time with no disruption of established natural balance and unfavourable impact on environment. It is very important to apply optimal rate of nutrients which could increase dry matter yield, but at the same time to preserve soil fertility and biodiversity. The results showed that floristic composition, abundance of different groups of soil microorganisms and hay yield of the Danthonietum calycinae grassland were strongly influenced by the application of different nitrogen rates and lime. Nitrogen fertilisers increase the presence of grass species and decrease legumes and plants from other families in harvested biomass. The application of nitrogen increased dry matter yield in all treatments, but the highest rate of nitrogen had adversely influence on microbial activity in soil. Liming changed the soil $\mathrm{pH}$, and indirectly had a positive effect on biodiversity, dry matter yield and soil microbes, except for fungi.

There were no significant differences between treatments $\mathrm{L}_{0} \mathrm{~N}_{140}$ and $\mathrm{L}_{1} \mathrm{~N}_{80}$ in dry matter yield, but microbial soil activity and plant biodiversity were much better preserved in the treatment with lime and lower dose $\left(\mathrm{N}_{80}\right)$ of nitrogen. Results indicated that optimal applications of nutrients for this association is application of PK and lime and $80 \mathrm{~kg}$ of nitrogen which enable high yield (6.38 tha $\left.\mathrm{a}^{-1}\right)$ in comparison with control (3.16 tha ${ }^{-1}$ ) preserving soil fertility and the environment. Long term effect on applied measures, especially lime, could be determined after few years, and it is a reason why it is necessary to continue the research in further period.

\section{Acknowledgements}

This study was supported by the Ministry of Education, Science and Technological Development of Republic of Serbia, Project TR 31057.

\section{Conflict of Interest}

The authors declare that there are no conflicts of interest related to this article.

\section{References}

Acosta-Martinez V, Tabatabai MA (2000). Enzyme activities in a limed agricultural soil. Biology and Fertility ofSoils 31(1):85-91.

Cincovic T, Kojic M (1955). Livadske fitocenoze Maljena [Meadow phytocenosis of Maljen]. Zbornik radova poljoprivrednog fakulteta, Beograd, III-1:113-118.

Čamska K, Skalova H (2012). Effect of low-dose N application and early mowing on plant species composition of mesophilous meadow grassland (Arrhenatherion) in Central Europe. Grass and Forage Science 67(3):403-410.

Čop J, Vidrih M, Hacin J (2009). Influence of cutting regime and fertilizer application on the botanical composition, yield and nutritive value of herbage of wet grasslands in Central Europe. Grass and Forage Science 64(4):454-465.
Elgersma A, HassinkJ (1997). Effect of white clover (Trifolium repens L.), on plant and soil nitrogen and soil organic matter in mixtures with perennial ryegrass (Lolium perenne L.). Plant and Soil 197(2):177-186.

Emstev VT (2000). Klebsiella planticola endophyte rhizobacteria and its interaction with plants. Acta Agriculturae Serbica 5(10):77-85.

Hejcman M, Klaudisova M, Schellberg J, Honsova D (2007). The Rengen Grassland Experiment: Plant species composition after 64 years of fertiliser application. Agriculture, Ecosystems and Environment 122(2):259-266.

Hejcman M, Schellberg J, Pavlů V (2010). Long-term effects of cutting frequency and liming on soil chemical properties, biomass production and plant species composition of Lolio-Cynosuretum grassland after the cessation of fertilizer application. Applied Vegetation Science 13(3):257269.

Honsova D, Hejcman M, Klaudisova M, Pavlu V, Kocourkova D, Hakl J (2007). Species composition of an alluvial meadow after 40 years of applying nitrogen, phosphorus and potassium fertilizer. Preslia Praha 79(3):245-258.

Hrevusova Z, Hejcman M, Hakl J, Mrkvicka J (2015). Soil chemical properties, plant species composition, herbage quality, production and nutrient uptake of an alluvial meadow after 45 years of $\mathrm{N}, \mathrm{P}$ and $\mathrm{K}$ application. Grass and Forage Science 70(2):205-218.

Jagnow $\mathrm{G}(1983)$. Nitrogenase $\left(\mathrm{C}_{2} \mathrm{H}_{2}\right)$ activity in roots of non-cultivated and cereal plants: influence of nitrogen fertilizer on populations and activity of nitrogen-fixing bacteria. Journal of Plant Nutrition and Soil Science $146(2): 217-227$.

Jarak M, Đurić S (2006). Praktikum iz mikrobiologije [Microbiology Practicum]. Poljoprivredni fakultet, Univerzitet u Novom Sadu.

Kemmitt SJ, Wright D, Jones DL (2005). Soil acidification used as a management strategy to reduce nitrate losses from agricultural land. Soil Biology and Biochemistry 37(5):867-875.

Kennedy N, Connolly J, Clipson N (2005). Impact of lime, nitrogen and plant species on fungal community structure in grassland microcosms. Environmental Microbiology 7(6):780-788.

Kojić M, Vukelić-Mrfat S, Dajic Z, Milošević-Đorđević S (2004). Livade i pašnjaci Srbije [Meadows and pastures in Serbia]. Monografija, Institut za istraživanja u poljoprivredi,Srbija.

Le Bauer SD, Treseder K (2008). Nitrogen limitation of net primary productivity in terresterial ecosystems is globally distributed. Ecology 89(2):371-379.

Lazarević D, Stošić M, DajićZ, Terzić D, Cvetković M (2009). Productivity and quality of plant mass of meadow ass. Danthonietum calycinae depending on the fertilization and utilization time. Biotechnology in Animal Husbandry, Belgrade Zemun 25(1-2):133-42.

Mandic L, Djukic D, Pesakovic M (2012). Microbial characteristics of vertisol under different fertilization systems. Journal of Central European Agriculture 13(1):1-9.

Milošević N, Tintor B, Dozet D, Cvijanović G (2007). Microbiological properties of soils in natural grasslands. Field and Vegetable Crops Research 44:541-546.

Mrfat Vukelić S, Kojić M, Stošić M (1991). Inventory of weed species in the meadow communites of Serbia (Yugoslavia). In: Proceedings of the Grassland renovation and weed control in Europe, European Grassland Federation, 18-21st September, Graz, pp 179-181. 
1062

PešakovićM,DukićDA, MandićL, RakićevićM, Miletić R(2009). Mineral fertilizers as a governing factor of the regulation of the number of fungi in soil.Journal for Natural Sciences 116:201-207.

Rouck J, Brookers SP, Bath E (2009). Contrasting soil pH effects on fungal and bacterial growth suggest functional redundancy in carbon mineralization. Applied Environmental Microbiolgy 75(6):1589-1596.

Smith J, Metzger J, Ewert F (2008). Spatial distribution of grassland productivity and land use in Europe. Agricultural Systems 98(3):208219.

Spiegelberger T, Hegg O, Matthies D, Hedlund K, Schaffner U (2006). Long-term effects of short-term perturbation in a subalpine grassland. Ecology 87(8):1939-1944.

Stanojković-Sebić A, Djukić D, Mandić L, Pivić R, Stojanović A, Josić D (2014). Mineral and bacterial fertilisation effect on the number of fungi in soil under winter wheat and the yield of wheat. Journal of Environmental Protection and Ecology 15(3):983-990.

Stark C, Condron LM, Stewart AD, O'Callaghan M (2007). Influence of organic and mineral amendments on microbial soil properties and processes. Applied SoilEcology 35(1):73-93.

StatSoft Inc. (2007). STATISTICA (data analysis software system), version 8.0. www.statsoft.com.

Stošić M, Lazarević D, Terzić D, Simić A (2004). Uticaj fosfora na proizvodnju stočne hrane na travnjacima [Effect of phosphorus in grassland-based livestock feed production]. Acta Agriculturae Serbica IX, 17:263-372
Valdés B, Scholz H, Raab-Straube E, Parolly G (2009). Poaceae (pro parte majore). Euro+MedPlantbase - the information resource for EuroMediterranean plant diversity. http://ww2.bgbm.org/EuroPlusMed/PTaxonDetailasp?NameCache $=$ Danthonia\%20alpina\&PTRefFk=7100000.

Vandenkoornhuyse P, Ridgway KP, Watson IJ, Fitter AH, Young JPW (2003). Co-existing grass species have distinctive arbuscular mycorrhizal communities. Molecular Ecology 12(11):3085-3095.

Velich J (1986). Studium vývoje produkční schopnosti trvalých lučních porostů a drnové hoprocesu pridlouho dobé mhnojení a jeho optimalizace [Study of development of yield capacity of grasslands under longterm fertilization and optimization of fertilization]. Vysoká škola zemědělskáv Praze, Agronomická fakulta, Praha.

Vučković S (2004). Travnjaci [Grasslands]. Monografija. Poljoprivredni fakultet, Zemun, Univerzitet u Beogradu.

Waler DM, Raaijmakers JM, McSpadden Gardner BB, Thomashow LS (2002). Microbial populations responsible for specific soil suppressiveness to plant pathogens. Annual Review of Phytopatology 40(1):309-348. 